\title{
Facile Route to Generate Fuel Oil via Catalytic Pyrolysis of Waste Polypropylene Bags: Towards Waste Management of $>20 \mu \mathrm{m}$ Plastic Bags
}

\author{
Neeraj Mishra, Sunil Pandey, Bhushan Patil, Mukeshchand Thukur, \\ Ashmi Mewada, Madhuri Sharon, and Maheshwar Sharon
}

\begin{abstract}
N. Shankaran Nair Research Center for Nanotechnology and Bionanotechnology, SICES College of Arts, Science and Commerece, Ambernath, Maharashtra 421505, India
\end{abstract}

Correspondence should be addressed to Neeraj Mishra; mishraneerajprakash@gmail.com

Received 17 April 2013; Accepted 29 July 2013; Published 2 January 2014

Academic Editors: X. Lu, A. W. Mohammad, and M. N. Siddiqui

Copyright (C) 2014 Neeraj Mishra et al. This is an open access article distributed under the Creative Commons Attribution License, which permits unrestricted use, distribution, and reproduction in any medium, provided the original work is properly cited.

\begin{abstract}
A novel strategy of waste recycling of polypropylene plastics (PP) bags for generation of commercially viable byproducts using nanoforms of nickel as catalyst is presented in this work. After pyrolysis of waste PP bags $(>20 \mu \mathrm{m})$ under continuous argon flow, $90 \%$ conversion efficiency to high petroleum oil was observed at $550^{\circ} \mathrm{C}$. To assess the physicochemical attributes of formed oil, flash point, pour point, viscosity, specific gravity, heating value, and density were also measured and found to be very close to ideal values of commercial fuel oil. Moreover, GC-MS was used to resolve the range of trace mass hydrocarbon present in the liquefied hydrocarbon. Our robust recycling system can be exploited as economical technique to solve the nuisance of waste plastic hazardous to ecosystem.
\end{abstract}

\section{Introduction}

Due to the nondegradability of PP plastics, their heavy accumulation in the environment is causing hostile effects on ecosystem including soil erosion [1]. Conventional routes to recycle PP plastics such as mechanical recycling, land filling, incineration, and chemical recycling [2] suffer from many hostile impacts such as landfill waste, clogged waterways, occupational health hazards, energy consumption, animal death, water contamination, foreign oil dependency, toxic pollution, soil degradation, costly production/recycling of plastics, and landscape litter. Additionally, these techniques have following limitations.

(1) Low-conversion efficiency.

(2) No valuable by products are formed; rather one form of plastic is converted to another, which has no commercial value.

(3) Requiring high energy and manual efforts.

(4) Heavy pollutants are generated during the process.
Keeping these cardinal issues under consideration, a facile route to convert waste plastics into high-performance fuel oil using high temperature pyrolysis is discussed in this paper. Fuel oil generated by our method was found to have all the characteristics to be used as fuel oil in factories. Since waste plastics like polypropylene (PP) contain $85 \%$ the carbon and rest is hydrogen, this makes them extremely suitable for feedstock recycling with the production of valuable hydrocarbon products. This fact can be explained with the difference in the activation energy of two polymers. PP requires lower activation energy to break the $\mathrm{C}-\mathrm{H}$ bond than polyethylene (PE) because carbon chain of PP polymer contains tertiary carbon atoms which have considerably lower resistance against degradation [3]. There are several products obtained from the catalytic pyrolysis of PP which are carbon nano-materials (CNMs) of different morphologies [4-6], wax [7-9], oil [10-13] and gases [3, 14]. Most of the works, concerned with production of oils from waste PP plastics, and conversion efficiency was found to be $<50 \%$.

Our main efforts were focused on converting WPP into less nonhazardous forms by ecofriendly method like 


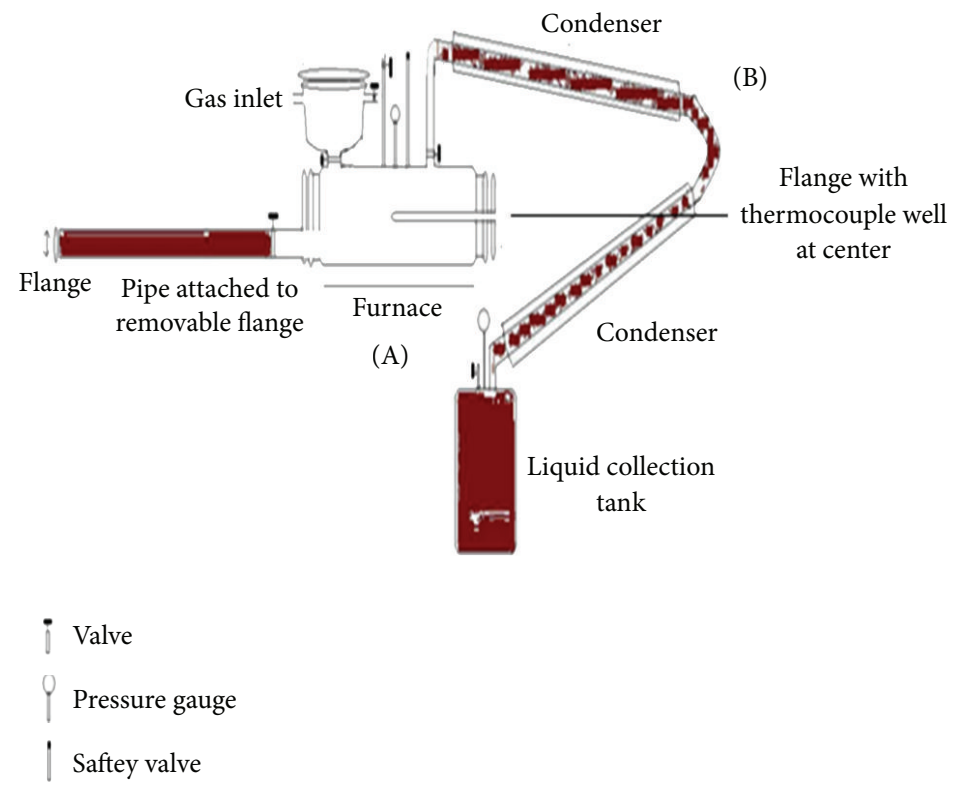

FIGURE 1: Schematic diagram of unit used for synthesizing liquefied hydrocarbon by catalytic pyrolysis reactor. In this diagram, stainless steel reactor (A), gas inlet, condenser (B), liquid collection tank, valve, pressure gauge, and safety valve have been shown.

catalytic pyrolysis. In our previous paper, conversion of $\mathrm{PP}$ to MWCNTs was reported [15]. However, during these conversion experiments, traces of liquid hydrocarbons were also noted. Therefore, a systematic study of oil-like liquefied hydrocarbon production was undertaken. This conversion has been demonstrated earlier by a simple thermal process in which polymers are melted and broken down to smaller molecules, at high temperature, into gaseous, liquid, and solid hydrocarbons [16]. Sarker et al. in 2012 [11] have performed thermal degradation of HDPE-2 in a fiber glass reactor system at a reaction temperature between 370 and $420^{\circ} \mathrm{C}$ and a reaction time of $4 \mathrm{~h}$ using HZSM-5 molecular sieves as catalyst to obtain hydrocarbon liquid fuel. Tymoshevskyy et al. in 2009 [17] have used pyrolysis method to convert $\mathrm{PP}, \mathrm{PE}$, and polystyrene (PS) waste to fuel with trial of several catalysts. They have separated the product of catalytic cracking used in a distillation column into gas, gasoline, light oil, and heavy oil fractions. Tiwari et al. in 2009 [12] have done the catalytic degradation of Linear Low Density PE (LLDPE) using two commercial cracking catalyst-1 and cracking catalyst- 2 containing $20 \%$ and $40 \%$ US-Y zeolite, respectively, with average particle size in micrometers at temperature of $600^{\circ} \mathrm{C}$ to produce light hydrocarbon fuel. Catalytic pyrolysis of LDPE was investigated using various fly ash-derived silicaalumina catalysts (FSAs) by $\mathrm{Na}$ et al. in 2006 [18]. In the present work, our trials involve simple catalyst preparation as well as cost effective pyrolysis reactor for the synthesis of liquefied hydrocarbons. Catalytic pyrolysis due to combined impact of pyrolysis and catalytic reforming is shown as a more efficient method for processing large amounts of waste plastics [19]. We have made an attempt to utilize WPP as potential precursor for synthesis of liquefied hydrocarbons using catalytic pyrolysis. The synthesis of liquefied hydrocarbons from waste PP plastics using $\mathrm{Ni}$ as a catalyst in reactor at pyrolysis temperature of $550^{\circ} \mathrm{C}$ is reported. It was observed by $\mathrm{Na}$ et al. in 2006 [18] and Pandian and Kamalakannan in 2012 [20], that liquefied hydrocarbon synthesized at lower temperature or below $500^{\circ} \mathrm{C}$ after 1-2 days turns into wax whereas oil prepared above $500^{\circ} \mathrm{C}$ remains as it is after long period of time. Synthesized liquefied product was characterized by GCMS. Moreover, its flash point, pour point, viscosity, specific gravity, and density were also measured.

\section{Experiment}

Waste PP was collected from Brihanmumbai Municipal Corporation (BMC) garbage disposal centre. Immediately after collection, WPP were washed, air-dried, and shredded into small pieces prior to pyrolysis in presence of nano-sized nickel as catalyst. To synthesize Ni catalyst, $10 \mathrm{~mL}$ of $5 \mathrm{mM}$ nickel nitrate was mixed with the same volume of ethanol under constant stirring for $2 \mathrm{hrs}$ [21]. One $\mathrm{kg}$ of shredded WPP was mixed with $10 \mathrm{~mL}$ of nickel (Ni) catalyst and subjected to pyrolysis as displayed in Figure 1.

Pyrolysis of waste plastic under controlled Ar (500 sccm) gas atmosphere at fixed temperature of $550^{\circ} \mathrm{C}$ (the ramp temperature of $10^{\circ} \mathrm{C} / \mathrm{min}$ was used during this whole reaction process until the required temperature was achieved) with $1 \mathrm{~h}$ of dwell time in the presence of $\mathrm{Ni}$ as catalyst resulted in production of liquefied hydrocarbon or oil. This liquid was collected after the furnace temperature was allowed to cool down naturally once the reaction time was over in the atmosphere of $100 \mathrm{sccm}$ of Ar gas (Figure 1). Due to high temperature, plastics get fragmented into monomers and reacted with catalyst and converted into the form of respective gases form which condense through condenser and are stored in the collection tank (Figure 1). 


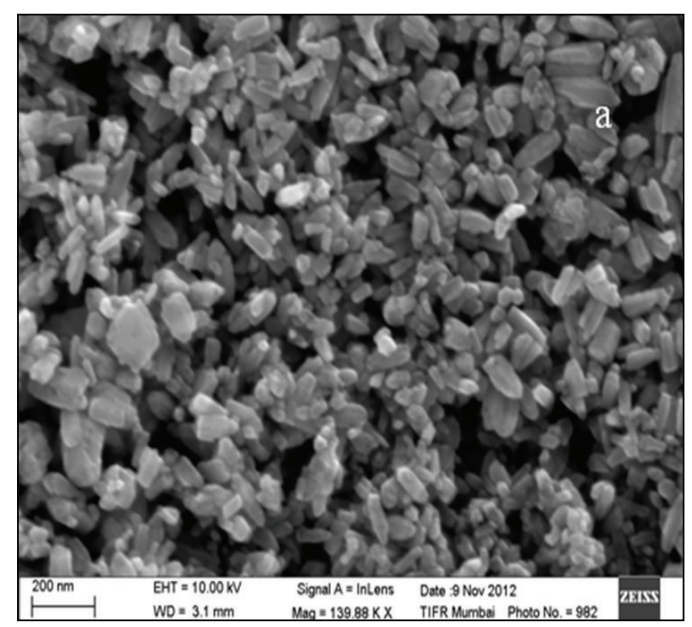

(a)

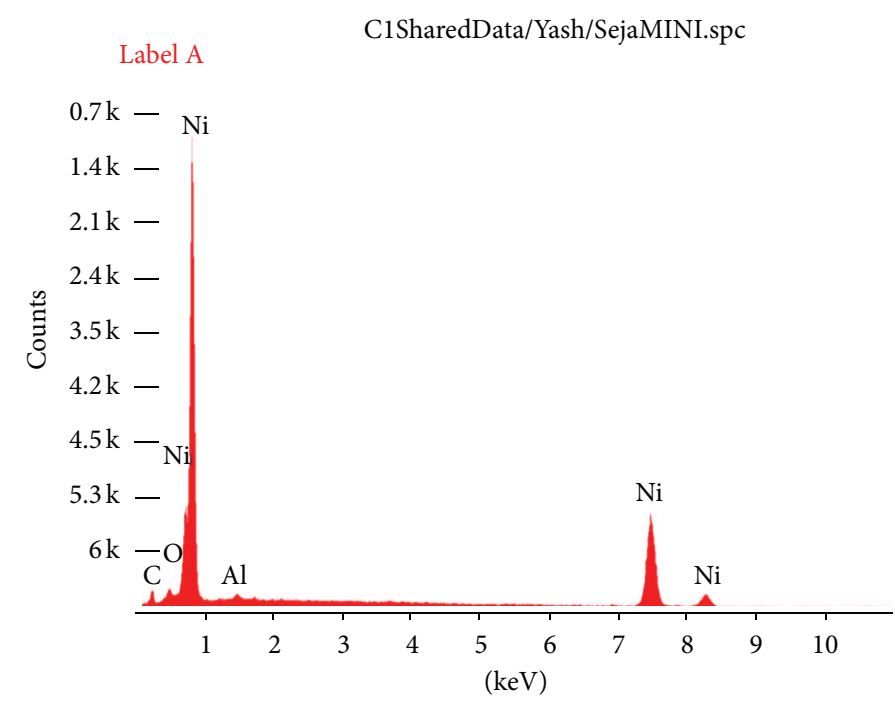

(b)

FIgURE 2: SEM and EDEX of Ni nanoparticles.

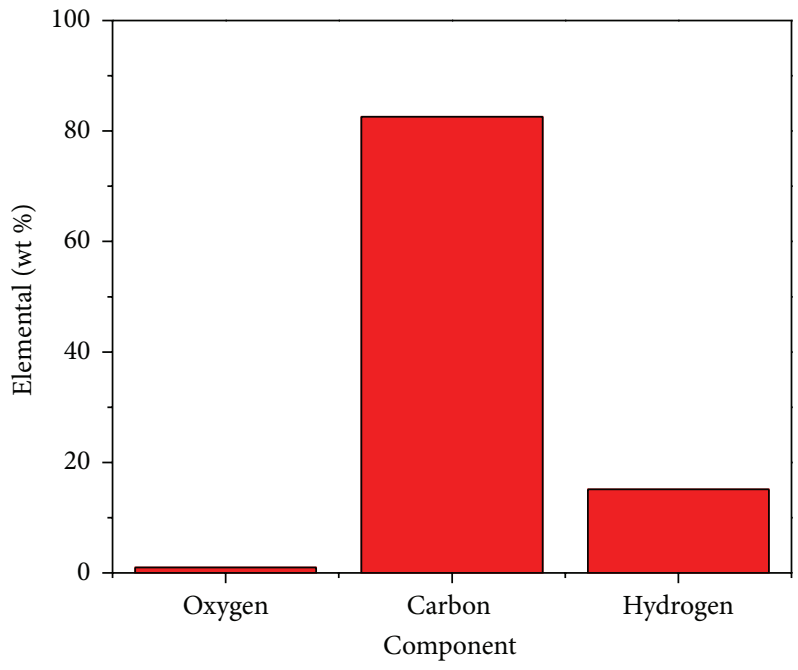

Figure 3: Elemental analysis of fuel oil.

\section{Characterisation Technique}

Gas chromatography coupled with high resolution mass spectrometer (GC-HRMS) was done by using an Agilent 7890 chromatograph with a $(15 \mathrm{~mm} \times 0.25 \mathrm{~mm} \times 0.25 \mu \mathrm{m})$ glass column packed with $80-100$ mesh n-octanes, Porasil C, and with a flame ionization detector (FID). In gas chromatography, helium gas at the flow rate $1.5 \mathrm{~mL} / \mathrm{min}$ was used as a carrier gas with a head space injection temperature of $250^{\circ} \mathrm{C}$. The oven temperature was programmed from $40^{\circ} \mathrm{C}$ ( $2 \mathrm{~min}$ hold) to $140^{\circ} \mathrm{C}$ (10 min hold) with heating ramp rate of $8^{\circ} \mathrm{C} / \mathrm{min}$. Data scan rate of the sample was kept at $0.6 \mathrm{sec} / \mathrm{scan}$ with mass scan range of 10 to $425 \mathrm{~m} / \mathrm{z}$.

Electron energy of mass spectrometer (Jeol, AccuTOF GCV) was $70 \mathrm{eV}$, and the ion source and coupling temperatures were 230 and $300^{\circ} \mathrm{C}$, respectively. The ion mass spectra derived were automatically compared to TLC, MS spectral libraries. Standard solutions were analyzed to verify the identity of the peaks by retention time and provide quantitative analysis.

Elemental analysis was carried out by CHNS (O) analyser of Thermo Finnigan (FLASH EA112 series) of IIT Bombay, Mumbai.

Density, API gravity, specific gravity, pour point, and flash point-all these tests of liquid hydrocarbon, were characterized by standard methods [20].

\section{Result and Discussion}

During the catalytic degradation of WPP, the following cardinal steps decided the efficiency of conversion.

(1) Size monodispersity of the catalyst.

(2) Ratio of WPP and catalyst. 
Comment: split50: 1,80-2M-10-200-3M-10-250-30-280-HP5- $\mathrm{CHCl}_{3}$

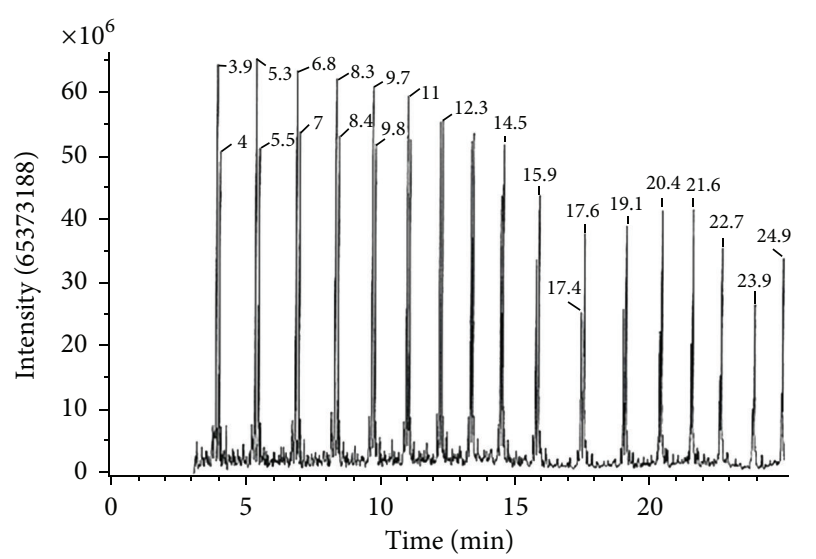

FIGURE 4: Total ion chromatogram of liquefied hydrocarbon obtained from the pyrolysis of waste $\mathrm{PP}$ at $550^{\circ} \mathrm{C}$ in the presence of $\mathrm{Ni}$ as catalyst for a duration of $1 \mathrm{hr}$ in atmosphere of Ar.
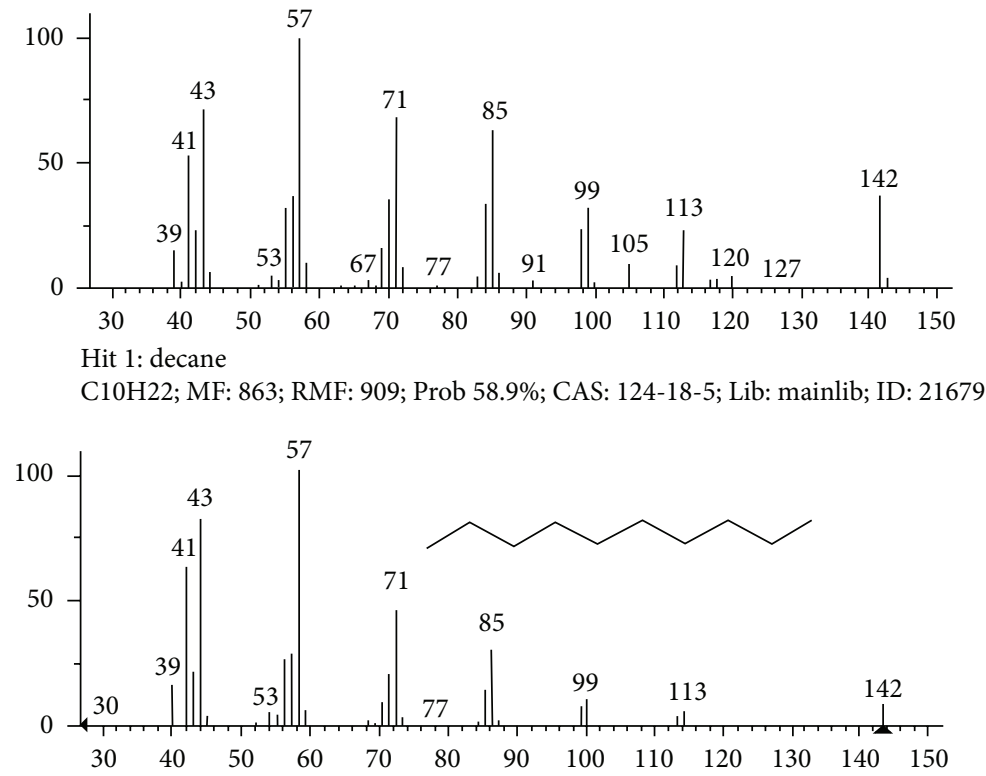

Hit 2: decane

C10H22; MF: 832; RMF: 880; Prob 58.9\%; CAS: 124-18-5; Lib: replib; ID: 2052

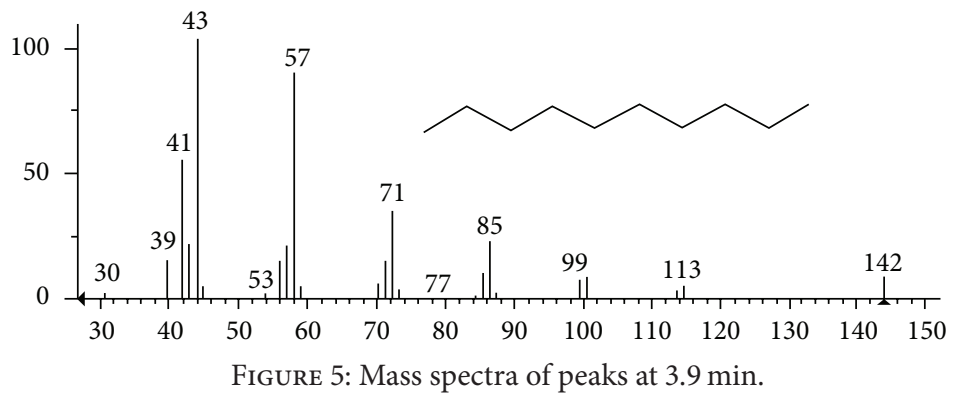

(3) Temperature gradient between site of pyrolysis (Figure 1(A)) and site of collection (Figure 1(B)).

As displayed in Figure 2, size of Ni catalyst was found to be ranging between 5 and $10 \mathrm{~nm}$. At nanoscale, enhanced catalytic activity of $\mathrm{Ni}$ involved in cracking and hydrogenation leads to efficient conversion of WPP to oil [22, 23]. Additionally, efficient diffusion of $\mathrm{Ni}$ during the process of pyrolysis helps to accelerate the entire reaction [24].

Ratio of WPP and catalyst $(1 \% \mathrm{w} / \mathrm{w})$ was also found to be vital parameter due to quantity-dependent reaction mechanism of Ni catalyst. At higher quantities, Ni influences 

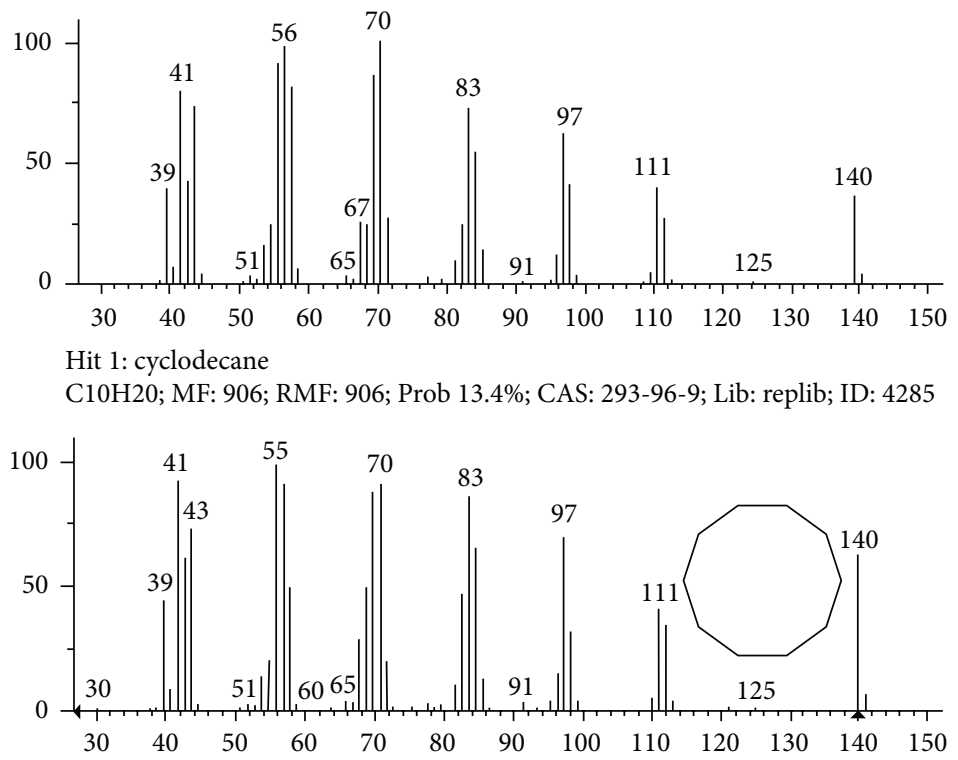

Hit 2: 1-decane

C10H20; MF: 901; RMF: 904; Prob 10.8\%; CAS: 872-05-9; Lib: replib; ID: 4200

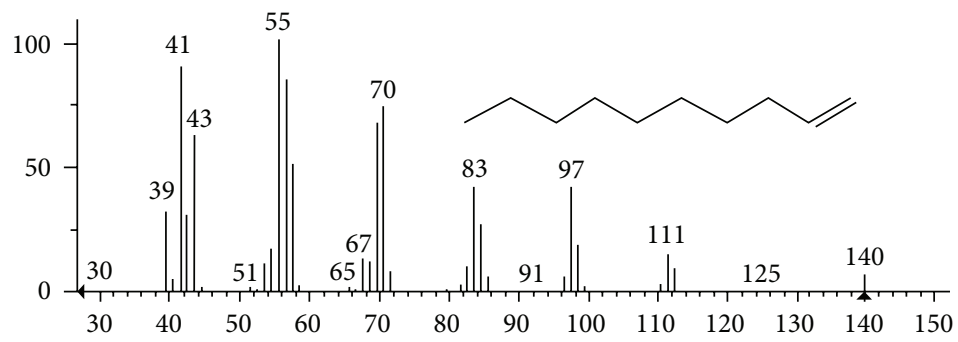

FIgURE 6: Mass spectra of peaks at $4 \mathrm{~min}$.

conversion of PP to higher aromatic compounds which leads to amorphous carbon, thus decreasing the yield of oil. This is also due to self-pyrolytic properties of aromatic compounds which get converted to amorphous carbon [25]. Conversion of WPP to oil mainly depends upon the vaporization followed by prompt condensation of vapours with the help of condenser. Due to unique design of our furnace, vaporisation of $\mathrm{PP}$ was initiated at $350^{\circ} \mathrm{C}$ followed by complete process at $550^{\circ} \mathrm{C}$. Till the vapours reach to condenser for the formation oil, there was sharp maintenance of temperature to avoid loss of higher carbon numbers (which may decrease the yield). This gradient in the temperature of the reaction vessel $\left(550^{\circ} \mathrm{C}\right)$ and condenser $\left(150^{\circ} \mathrm{C}\right.$ ) was possible due to kink (Figure $1(\mathrm{~B})$ ) separating the vapours at high as well as low temperatures.

Most preliminary analysis of the oil was its visual inspection of the colour obtained after catalytic pyrolysis of WPP. The appearance of oil was transparent and yellowish red in colour. The oil obtained from the pyrolysis was fractionated by distillation and the fuel properties were studied. Elemental composition of fuel oil is found to be $\mathrm{C}(83 \%), \mathrm{H}(14 \%)$, and $\mathrm{O}$ (1\%) which confirmed hydrocarbon nature of oil (Figure 3). A comparative analysis of sulfur content, pour point, viscosity, and distillation recovery of oil synthesized using various methods is presented in Table 1. Pour point of the sample was found to be less than $10^{\circ} \mathrm{C}$, which is in accordance with the standard values of fuel oil [26]. Flash points, density, acidity of fuel oil were found to be $\sim 40^{\circ} \mathrm{C}, 0.7930 \mathrm{~g} / \mathrm{mL}$, and 0.76 , respectively. All the above values were found to be standard values of fuel oil $[11,27]$.

American Petroleum Institute (API) gravity of liquefied hydrocarbon prepared from waste plastics was found to be 46.67. There is an inverse relationship between API gravity and density; that is, the higher the density, the lower the API gravity. Light crude is generally that with API gravity over 40 [20]. Therefore, liquefied hydrocarbon produced from our pyrolysis system was found to be light.

Specific gravity of liquefied hydrocarbon prepared from pyrolysis of waste $\mathrm{PP}$ was estimated to be 0.7932 at $15^{\circ} \mathrm{C}$ which is similar to specific gravity of petroleum (density compared to water), that is, $0.8[20,29]$.

Liquefied hydrocarbon synthesized from pyrolysis of WPP has 25 ppm (0.0025\%) of sulfur content which is very less compared to standard fuel oil. Fuel oil is normally described as sweet (low sulfur) or sour (high sulfur) depending on their sulfur content. Sweet fuel oil has sulfur content less than $0.5 \%$, and anything more than that is sour. Sweet oil is more preferable than the sour due to its applicability to produce most of the refined products [18, 27]. Another 
TABLE 1: Comparative study of physical properties of fuel oil obtained by WPP with other waste plastic products.

\begin{tabular}{|c|c|c|c|c|c|c|c|}
\hline SR. no. & Test & $\begin{array}{l}\text { Method of } \\
\text { testing }\end{array}$ & Result & $\begin{array}{l}\text { Waste LDPE } \\
{[20]}\end{array}$ & $\begin{array}{c}\text { Waste mixed } \\
\text { plastic } \\
{[12]}\end{array}$ & $\begin{array}{l}\text { Waste HDPE } \\
\text { [27] }\end{array}$ & $\begin{array}{l}\text { Gulf fuel oil } \\
\quad[28]\end{array}$ \\
\hline 1 & Density@15ㄷ & $\begin{array}{l}\text { ASTM D } \\
\text { 4052:2002 }\end{array}$ & $0.7930 \mathrm{~g} / \mathrm{mL}$ & $0.8760 \mathrm{~g} / \mathrm{mL}$ & NA & $0.7828 \mathrm{~g} / \mathrm{mL}$ & NA \\
\hline 2 & Acidity (mg KOH/g) & $\begin{array}{l}\text { ASTM D } \\
974: 2002\end{array}$ & 0.76 & Nil & NA & NA & Nil \\
\hline 3 & API gravity@60 F & $\begin{array}{l}\text { ASTM D } \\
1298: 1999\end{array}$ & 46.67 & NA & 60.65 & NA & 31.4 \\
\hline 4 & Flash point COC & $\begin{array}{l}\text { ASTM D } \\
92-05 a\end{array}$ & $<40^{\circ} \mathrm{C}$ & $45^{\circ} \mathrm{C}$ & 22 & Plus $1^{\circ} \mathrm{C}$ & NA \\
\hline 5 & Kinematic viscosity @ 40 $\mathrm{C}$ & $\begin{array}{l}\text { ASTM D } \\
445: 2005\end{array}$ & $2.149 \mathrm{~mm}^{2} / \mathrm{s}$ & $1.47 \mathrm{~mm}^{2} / \mathrm{s}$ & NA & $1.63 \mathrm{~mm}^{2} / \mathrm{s}$ & 5.69 \\
\hline 6 & Colour & $\begin{array}{l}\text { ASTM D } \\
1500: 2004 \mathrm{a}\end{array}$ & $\begin{array}{l}\text { D } 8 \text { (light } \\
\text { yellowish- } \\
\text { red clear) }\end{array}$ & NA & Pale yellow & $\begin{array}{l}\text { Dark } \\
\text { brownish } \\
\text { clear }\end{array}$ & Orange \\
\hline 7 & Conradson carbon residue & $\begin{array}{l}\text { ASTM D } \\
\text { 189:2005 }\end{array}$ & $0.010 \%(\mathrm{wt} \%)$ & NA & NA & $0.01 \%$ & NA \\
\hline 8 & Asphaltene content & $\begin{array}{l}\text { ASTM D } \\
3279: 2001\end{array}$ & $0.21(w t \%)$ & NA & NA & NA & NA \\
\hline 9 & Ash content & $\begin{array}{l}\text { ASTM D } \\
482: 2003\end{array}$ & $<0.01 \%(w t)$ & $0.02 \%$ & NA & NA & NA \\
\hline 10 & $\begin{array}{l}\text { Calculated carbon aromatic } \\
\text { index }\end{array}$ & ISO $8217: 1996$ & 763.4 & NA & NA & NA & NA \\
\hline 11 & Pour point & $\begin{array}{l}\text { ASTM D } \\
97-05 \mathrm{a}\end{array}$ & Minus $10^{\circ} \mathrm{C}$ & NA & $<-20^{\circ} \mathrm{C}$ & Minus $15^{\circ} \mathrm{C}$ & $1.6^{\circ} \mathrm{C}$ \\
\hline 12 & Sediment by extraction & $\begin{array}{l}\text { ASTM D } \\
\text { 473:2002 }\end{array}$ & $0.012(w t)$ & 0.001 & NA & NA & NA \\
\hline 13 & Specific gravity @ $15^{\circ} \mathrm{C}$ & $\begin{array}{c}\text { ASTM D } \\
\text { 4052:2002 }\end{array}$ & 0.7932 & NA & 0.7365 & 0.7835 & 0.8690 \\
\hline 14 & Sulphur content & $\begin{array}{l}\text { ASTM D } \\
4094: 2003\end{array}$ & $0.0025 \%$ & $0.083 \%$ & $0.002 \%$ & $0.019 \%$ & $0.09 \%$ \\
\hline 15 & Water by distillation & $\begin{array}{l}\text { ASTM D } \\
95-05 \mathrm{el}\end{array}$ & $<0.05 \%$ & $0.01 \%$ & NA & NA & $0.05 \%$ \\
\hline 16 & Calorific value & $\begin{array}{l}\text { ASTM D } \\
240 \mathrm{cal} / \mathrm{g}\end{array}$ & 10,000 & 10,810 & 10,498 & 10,244 & 10,460 \\
\hline \multirow[t]{15}{*}{17} & Distillation range & $\begin{array}{l}\text { ASTM D } \\
86: 04 b\end{array}$ & & & & & \\
\hline & Initial boiling range & & $71^{\circ} \mathrm{C}$ & & & 82 & \\
\hline & $5 \%$ recovery & & $110^{\circ} \mathrm{C}$ & & & & \\
\hline & $10 \%$ recovery & & $141^{\circ} \mathrm{C}$ & & & 126 & \\
\hline & $20 \%$ & & $185^{\circ} \mathrm{C}$ & & & & \\
\hline & $30 \%$ & & $226^{\circ} \mathrm{C}$ & & & 188 & \\
\hline & $40 \%$ & & $261^{\circ} \mathrm{C}$ & & & & \\
\hline & $50 \%$ & & $291^{\circ} \mathrm{C}$ & & & 226 & \\
\hline & $60 \%$ & & $319^{\circ} \mathrm{C}$ & & & & \\
\hline & $70 \%$ & & $343^{\circ} \mathrm{C}$ & & & 278 & \\
\hline & $80 \%$ & & $365^{\circ} \mathrm{C}$ & & & & \\
\hline & $85 \%$ & & $380^{\circ} \mathrm{C}$ & & & & \\
\hline & $90 \%$ & & $390^{\circ} \mathrm{C}$ & & & 320 & \\
\hline & $100 \%$ & & $400^{\circ} \mathrm{C}$ & \multirow[t]{2}{*}{$85.3 \%$} & & 352 & \multirow[t]{2}{*}{$99.6 \%$} \\
\hline & Total recovery & & $90 \%$ & & & $95 \%$ & \\
\hline
\end{tabular}

*NA: not available. 


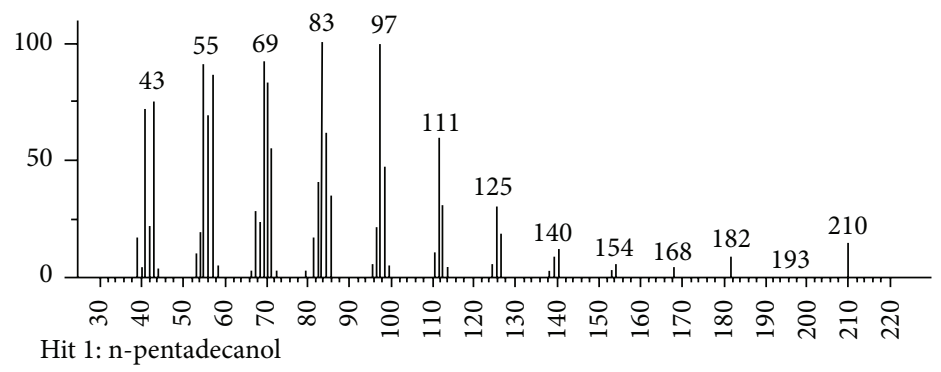

C15H32O; MF: 914; RMF: 915; Prob 12.1\%; CAS: 629-76-5; Lib: replib; ID: 1980
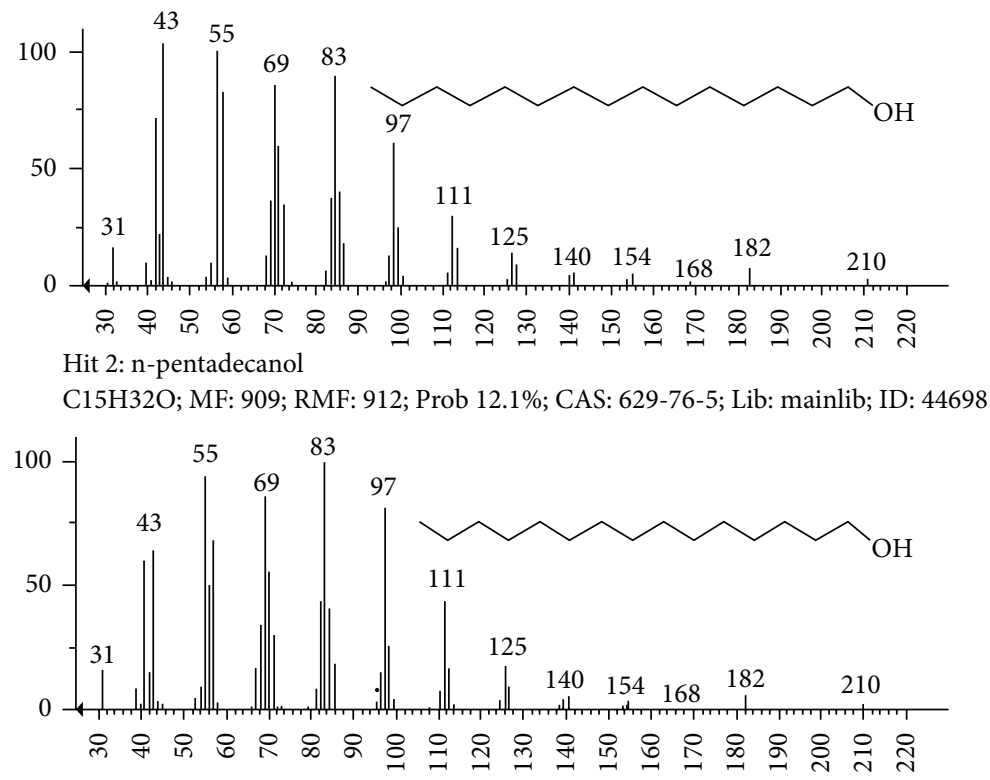

Figure 7: Mass spectra of peaks at $11 \mathrm{~min}$.

important attribute was found to be kinematic viscosity of liquefied hydrocarbon synthesized from waste plastic that was estimated to be $2.149 \mathrm{~mm}^{2} / \mathrm{s}$ at $40^{\circ} \mathrm{C}$. As per the standard kinematic viscosities of fuel oil $\left(3.5-9.7 \mathrm{~mm}^{2} / \mathrm{s}\right)$, oil formed by our method was found to be less viscous [20, 30, 31].

Calorific value of oil synthesized from pyrolysis of waste plastic was recorded to be $10,000 \mathrm{cal} / \mathrm{g}(41.86 \mathrm{MJ} / \mathrm{kg})$, whereas Calorific values of various fuel oils, for example, diesel, gasoline, petrol and petroleum fuel are 44.8, 47.3, 48 and $43 \mathrm{MJ} / \mathrm{Kg}$ respectively $[20,30,31]$. Hence, it can be said that this liquefied hydrocarbon obtained from waste plastic can be used for fuel.

From the distillation report of the liquefied hydrocarbon, it was found that boiling range of the oil is $71-390^{\circ} \mathrm{C}$, which suggests the presence of a mixture of different fractions such as gasoline, kerosene, and diesel [17, 20, 30-32].

A typical GC chromatogram diagram for the liquid fraction taken from plastics pyrolysis is illustrated in Figure 4. It is clear that chromatogram obtained in high efficient column contains two dominant products which are alk-1enes and n-alkanes in the range C6-C23, with only a small proportion of cyclic and alcoholic substances. Besides these main mixed plastics decomposition products, chromatogram is fully occupied by several hundred small peaks of other compounds including broad peak of many unresolved compounds which is characteristic for multicomponent hydrocarbon mixtures. This is due to low pyrolysis temperature. Furthermore, a detailed list of all hydrocarbons detected in the liquid fraction of pyrolysis of waste products based on high-density polyethylene (HDPE) and low-density polyethylene (LDPE) was well explained by Achilias et al. in 2007 [8]. It was observed that pyrolysis of the plastic bag made from $\mathrm{PE}$ and $\mathrm{PP}$ leads to a fraction mainly in the region of $\mathrm{C} 7-\mathrm{C} 12$, which is in the gasoline region. Also, the main components were alkanes and alkenes. A mass spectrum indicates that the fragment of polymers contains only one carbon atom; this is due to the fragmentation at interval of $-\mathrm{CH}_{2}$ break from long chain. Mass spectra at different time intervals show that oil contained alkanes, alkenes, some cycloalkanes, and alcohol. Mass spectra at 3.9 min show that oil might contain cycloalkane and alkenes like cyclodecane and 1-decene, respectively (Figure 5). There are some aliphatic alkanes found to be present at time interval of $4 \mathrm{~min}$ having $\mathrm{m} / \mathrm{z}$ ratio of 142 corresponds to decane $\left(\mathrm{C}_{10} \mathrm{H}_{22}\right)$ (Figure 6). It is seen from Figure 7 that there are some higher alcoholic groups like n-pentadecanol $\left(\mathrm{C}_{15} \mathrm{H}_{32} \mathrm{O}\right)$. Figure 8 indicates higher alkanes, present at interval time of 29.4 minutes; they are nonacosane $\left(\mathrm{C}_{29} \mathrm{H}_{60}\right)$ and triacontane $\left(\mathrm{C}_{30} \mathrm{H}_{62}\right)$. It 
Unknown: MDT[CTR[30.0000..30.0000, 10, center, 80, 0.0, area]; SMT[SA, 3]] E45SICESC.7fNESICES1.7rw

Compund in library factor $=-185$

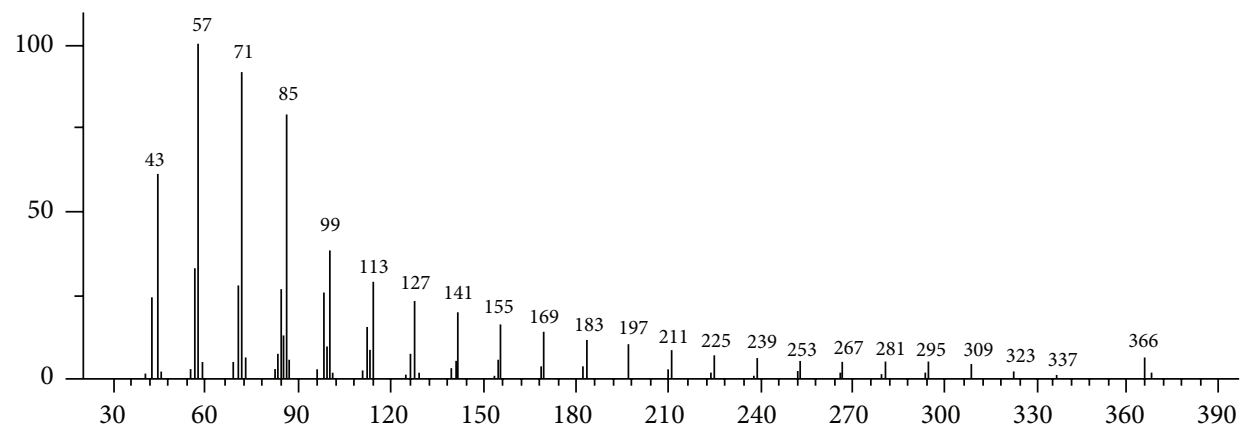

Hit 1: nonacosane

C29H60; MF: 889; RMF: 898; Prob 15.0\%; CAS: 630-03-5; Lib: mainlib; ID: 22762

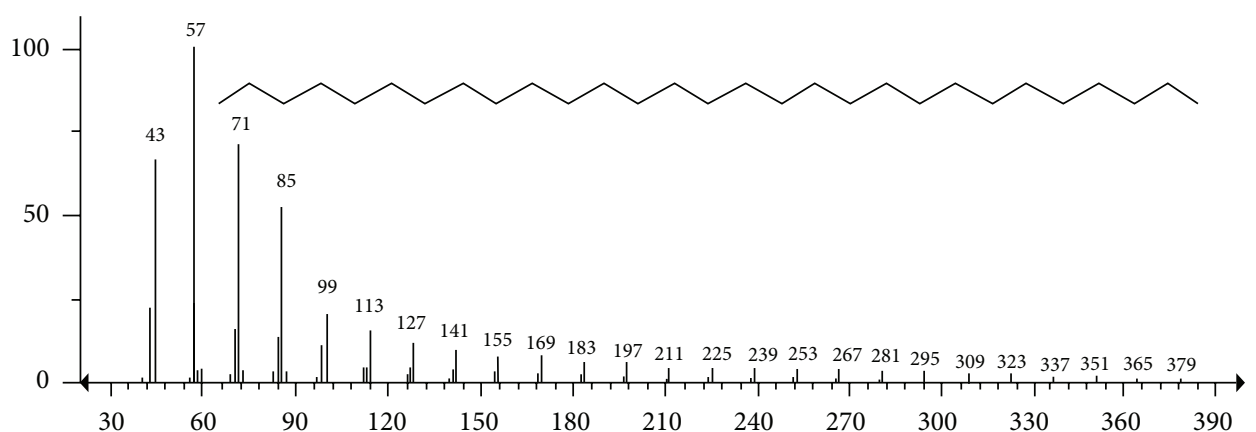

Hit 2: triacontane

C30H62; MF: 888; RMF: 900; Prob 14.4\%; CAS: 638-68-6; Lib: mainlib; ID: 22894

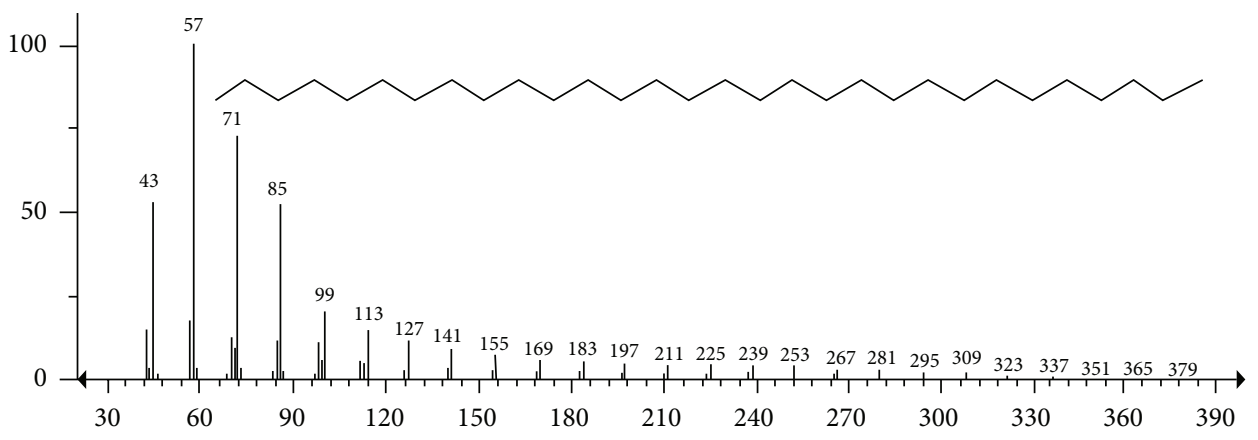

FIGURE 8: Mass spectra of peaks at $29.4 \mathrm{~min}$.

is concluded from the GC-MS data that oil contain alkanes, alkenes, cyclic alkanes, and some alcoholic groups.

\section{Mechanism of Catalytic Degradation of Plastics}

The presence of a small amount of Ni catalyst could efficiently promote the dehydrogenation of PP into light hydrocarbons. It was because that the Ni catalyst attacked PP surface to form cationic active sites and promoted the formation of more molecules with a lower carbon number by a cationic mechanism [14, 15]. Catalysts such as metal oxides have appeared to be used mainly for enhancement of monomer recovery [32]. Degradation of PP on nickel oxide solution yield more oils than that on solid acids, and time required to complete degradation on nickel oxide is lower than on solid acids. The composition of oil on metal oxide $(\mathrm{NiO})$ is reported to be rich in 1-olefins and is poor in aromatics and branched isomers. In our case, plastics reacted with catalyst and were converted into smaller fragments or monomers. As the temperature increases these fragments are converted into vapour state which condense to give fuel oil. Octane number is expected to be low for the oils produced on solid bases, since the oils mainly consisted of straight chain hydrocarbons: n-paraffins, and 1-olefins. From an economic point of view, reducing the cost even further will make this process an even more attractive option. This option can be optimized by reuse of catalysts and the use of effective 
catalysts in smaller quantities $[28,33]$. This method seems to be the most promising to be developed into a cost-effective commercial plastic waste recycling process to solve the keen environmental problem of plastic waste disposal.

\section{Conclusion}

Catalytic degradation of waste plastics in the presence of $\mathrm{Ni}$ catalyst for duration of $1 \mathrm{~h}$ in presence of Ar atmosphere leads to following concluding remarks.

(1) Conversion efficiency of $\mathrm{Ni}$ catalysed pyrolysis of WPP was found to be more than $90 \%$ yield. The catalytic degradation process produces much less residue content than that from thermal degradation.

(2) Physicochemical properties of obtained fuel oil can be exploited to make highly efficient fuel or furnace oil after blending with other petroleum products.

(3) The knowledge of design and process of the semiscale plant will be helpful for developing a commercial scale plant in the future. From this result, it can be concluded that the fuel properties of the catalytic pyrolysis oil match the properties of petroleum fuels.

\section{Highlights}

(i) Ecofriendly method for waste management of polypropylene plastics.

(ii) Use of nano-sized catalyst to enhance the rate of conversion of waste plastics to fuel oil.

(iii) Ideal properties of fuel oil for efficient commercial usage.

(iv) Unique design of the furnace to facilitate efficient conversion.

\section{Conflict of Interests}

The authors declare that there is no conflict of interests regarding the publication of this paper.

\section{Acknowledgments}

The authors would like to thank the Ministry of New and Renewable Energy (MNRE, India) and the University Grant Commission (UGC) for financial support and the management committee and the staff of the N. Shankaran Nair Research Center (NSNRC, Ambernath, India) for carrying out experiments and providing laboratory facilities.

\section{References}

[1] G. Luo, T. Suto, S. Yasu, and K. Kato, "Catalytic degradation of high density polyethylene and polypropylene into liquid fuel in a powder-particle fluidized bed," Polymer Degradation and Stability, vol. 70, no. 1, pp. 97-102, 2000.

[2] N. Miskolczi, L. Bartha, and A. Angyal, "High energy containing fractions from plastic wastes by their chemical recycling," Macromolecular Symposia, vol. 245-246, pp. 599-606, 2006.
[3] A. Marcilla, M. I. Beltrán, and R. Navarro, "Evolution of products generated during the dynamic pyrolysis of LDPE and HDPE over HZSM5," Energy and Fuels, vol. 22, no. 5, pp. 29172924, 2008.

[4] Y. Ando, X. Zhao, T. Sugai, and M. Kumar, "Growing carbon nanotubes," Materials Today, vol. 7, no. 9, pp. 22-29, 2004.

[5] D. Pradhan, M. Sharon, M. Kumar, and Y. Ando, "Nanooctopus: a new form of branching carbon nanofiber," Journal of Nanoscience and Nanotechnology, vol. 3, no. 3, pp. 215-217, 2003.

[6] S. Iijima, "Helical microtubules of graphitic carbon," Nature, vol. 354, no. 6348, pp. 56-58, 1991.

[7] P. S. Umare, R. Antony, K. Gopalakrishnan, G. L. Tembe, and B. Trivedi, "Synthesis of low molecular weight polyethylene waxes by a titanium BINOLate-ethylaluminum sesquichloride catalyst system," Journal of Molecular Catalysis A, vol. 242, no. 1-2, pp. 141-150, 2005.

[8] D. S. Achilias, C. Roupakias, P. Megalokonomos, A. A. Lappas, and V. Antonakou, "Chemical recycling of plastic wastes made from polyethylene (LDPE and HDPE) and polypropylene (PP)," Journal of Hazardous Materials, vol. 149, no. 3, pp. 536-542, 2007.

[9] R. Aguado, M. Olazar, M. J. San José, B. Gaisán, and J. Bilbao, "Wax formation in the pyrolysis of polyolefins in a conical spouted bed reactor," Energy and Fuels, vol. 16, no. 6, pp. 1429$1437,2002$.

[10] W. Kaminsky, M. Predel, and A. Sadiki, "Feedstock recycling of polymers by pyrolysis in a fluidised bed," Polymer Degradation and Stability, vol. 85, no. 3, pp. 1045-1050, 2004.

[11] M. Sarker, M. M. Rashid, and M. Molla, "Abundant HighDensity Polyethylene (HDPE-2) turns into fuel by using of HZSM-5 catalyst," Journal of Fundamentals of Renewable Energy and Applications, vol. 1, pp. 1-12, 2012.

[12] D. C. Tiwari, E. Ahmad, and K. Singh, "Catalytic degradation of waste plastic into fuel range hydrocarbons," International Journal of Chemical Research, vol. 1, pp. 31-36, 2009.

[13] Y.-H. Lin and H.-Y. Yen, "Fluidised bed pyrolysis of polypropylene over cracking catalysts for producing hydrocarbons," Polymer Degradation and Stability, vol. 89, no. 1, pp. 101-108, 2005.

[14] L. Soják, R. Kubinec, H. Jurdáková, E. Hájeková, and M. Bajus, "High resolution gas chromatographic-mass spectrometric analysis of polyethylene and polypropylene thermal cracking products," Journal of Analytical and Applied Pyrolysis, vol. 78, no. 2, pp. 387-399, 2007.

[15] N. Mishra, G. Das, A. Ansaldo et al., "Pyrolysis of waste polypropylene for the synthesis of carbon nanotubes," Journal of Analytical and Applied Pyrolysis, vol. 94, pp. 91-98, 2012.

[16] F. Pinto, P. Costa, I. Gulyurtlu, and I. Cabrita, "Pyrolysis of plastic wastes-1. Effect of plastic waste composition on product yield," Journal of Analytical and Applied Pyrolysis, vol. 51, no. 1, pp. 39-55, 1999.

[17] B. Tymoshevskyy, L. Malyi, M. Tkach, and G. Bykovchenko, "Utilization efficiency of aramide polymeric materials of the cases of solid-propellant missiles," World Academy of Science, Engineering and Technology, vol. 52, pp. 80-82, 2009.

[18] J.-G. Na, B.-H. Jeong, S. H. Chung, and S. Kim, "Pyrolysis of low-density polyethylene using synthetic catalysts produced from fly ash," Journal of Material Cycles and Waste Management, vol. 8, pp. 126-132, 2006.

[19] A. R. Songip, T. Masuda, H. Kuwahara, and K. Hashimoto, "Test to screen catalysts for reforming heavy oil from waste plastics," Applied Catalysis B, vol. 2, no. 2-3, pp. 153-164, 1993. 
[20] S. Pandian and A. Kamalakannan, "Catalytic pyrolysis of dairy industrial waste LDPE film into fuel," International Journal of Chemical Research, vol. 3, pp. 52-55, 2012.

[21] K. N. Kim and S.-G. Kim, "Nickel particles prepared from nickel nitrate with and without urea by spray pyrolysis," Powder Technology, vol. 145, no. 3, pp. 155-162, 2004.

[22] A. R. Ardiyanti, S. A. Khromova, R. H. Venderbosch, V. A. Yakovlev, and H. J. Heeres, "Catalytic hydrotreatment of fastpyrolysis oil using non-sulfided bimetallic $\mathrm{Ni}-\mathrm{Cu}$ catalysts on a $\delta$ - $\mathrm{Al}_{2} \mathrm{O}_{3}$ support," Applied Catalysis B, vol. 117-118, pp. 105-117, 2012.

[23] X. Zhang, T. Wang, L. Ma, Q. Zhang, and T. Jiang, "Hydro treatment of bio-oil over Ni-based catalyst," Bioresource Technology, vol. 127, pp. 306-311, 2012.

[24] K.-H. Lee and D.-H. Shin, "Catalytic degradation of waste polyolefinic polymers using spent FCC catalyst with various experimental variables," Korean Journal of Chemical Engineering, vol. 20, no. 1, pp. 89-92, 2003.

[25] Z. Jiang, R. Song, W. Bi, J. Lu, and T. Tang, "Polypropylene as a carbon source for the synthesis of multi-walled carbon nanotubes via catalytic combustion," Carbon, vol. 45, no. 2, pp. 449-458, 2007.

[26] N. X. Thanh, M. Hsieh, and R. P. Philp, "Waxes and asphaltenes in crude oils," Organic Geochemistry, vol. 30, no. 2-3, pp. 119-132, 1999.

[27] S. Kumar and R. K. Singh, "Recovery of hydrocarbon liquid from waste high density polyethylene by thermal pyrolysis," Brazilian Journal of Chemical Engineering, vol. 28, no. 4, pp. 659-667, 2011.

[28] G. Chauhan, K. K. Pant, and K. D. P. Nigam, "Extraction of nickel from spent catalyst using biodegradable chelating agent EDDS," Industrial \& Engineering Chemistry Research, vol. 51, pp. 10354-10363, 2012.

[29] P. Hudec, M. Horňáček, A. Smiešková, and P. Duač́lk, "Chemical recycling of waste hydrocarbons in catalytic cracking," Petroleum \& Coal, vol. 51, pp. 51-58, 2009.

[30] S. Murugan, M. C. Ramaswamy, and G. Nagarajan, "The use of tyre pyrolysis oil in diesel engines," Waste Management, vol. 28, no. 12, pp. 2743-2749, 2008.

[31] M. Sarker, M. M. Rashid, M. S. Rahman, and M. Molla, "Alternative diesel grade fuel transformed from polypropylene (PP) municipal waste plastic using thermal cracking with fractional column distillation," Energy and Power Engineering, vol. 4, pp. 165-172, 2012.

[32] A. G. Buekens and H. Huang, "Catalytic plastics cracking for recovery of gasoline-range hydrocarbons from municipal plastic wastes," Resources, Conservation and Recycling, vol. 23, no. 3, pp. 163-181, 1998.

[33] S. Goel, K. K. Pant, and K. D. P. Nigam, "Extraction of nickel from spent catalyst using fresh and recovered EDTA," Journal of Hazardous Materials, vol. 171, no. 1-3, pp. 253-261, 2009. 


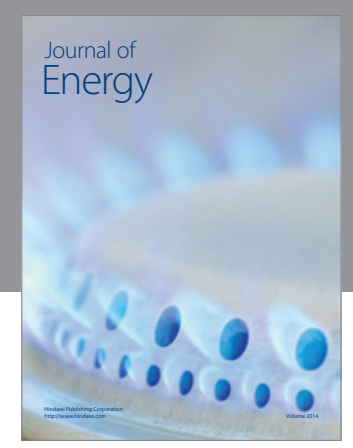

Journal of

Industrial Engineering
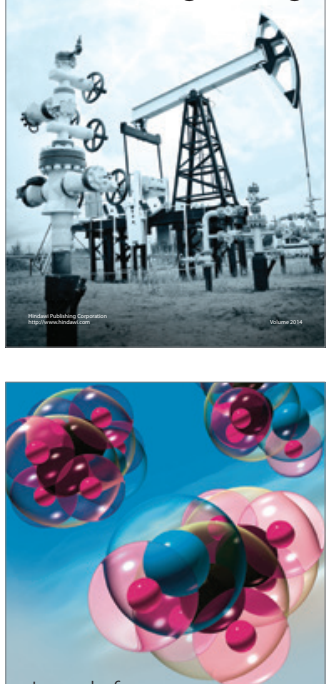

Fuels
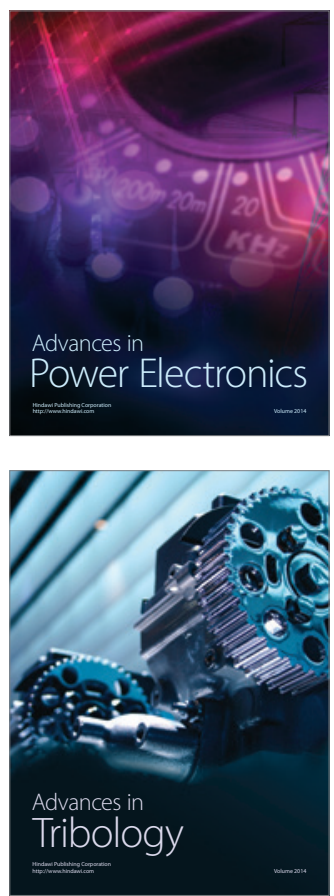

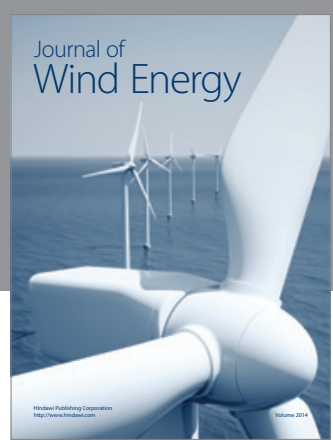

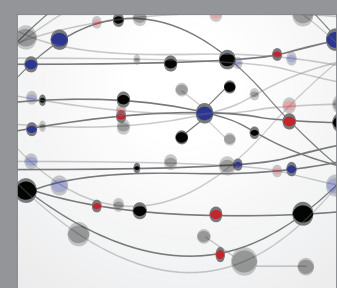

The Scientific World Journal

Submit your manuscripts at http://www.hindawi.com

Journal of

Structures
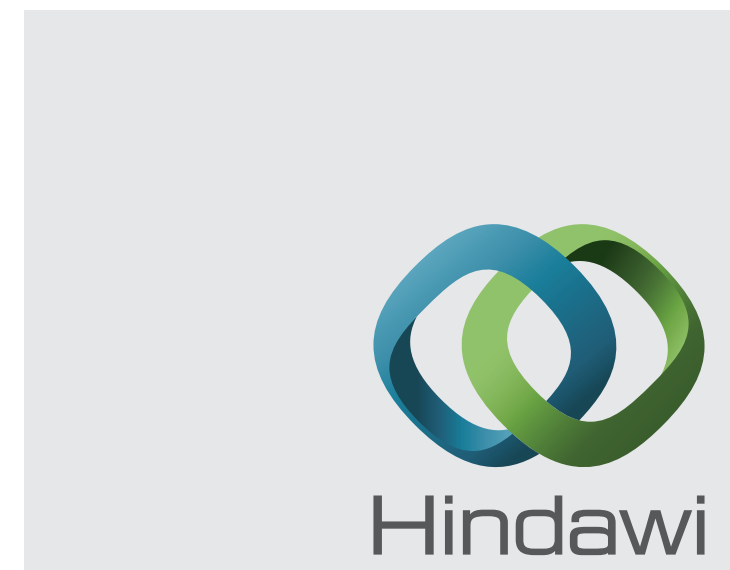

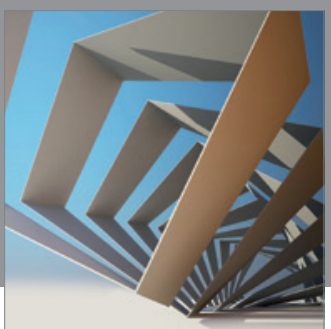

Rotating

Machinery
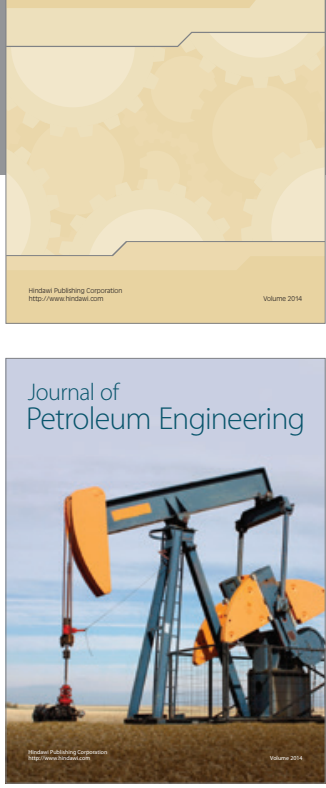

Journal of

Solar Energy
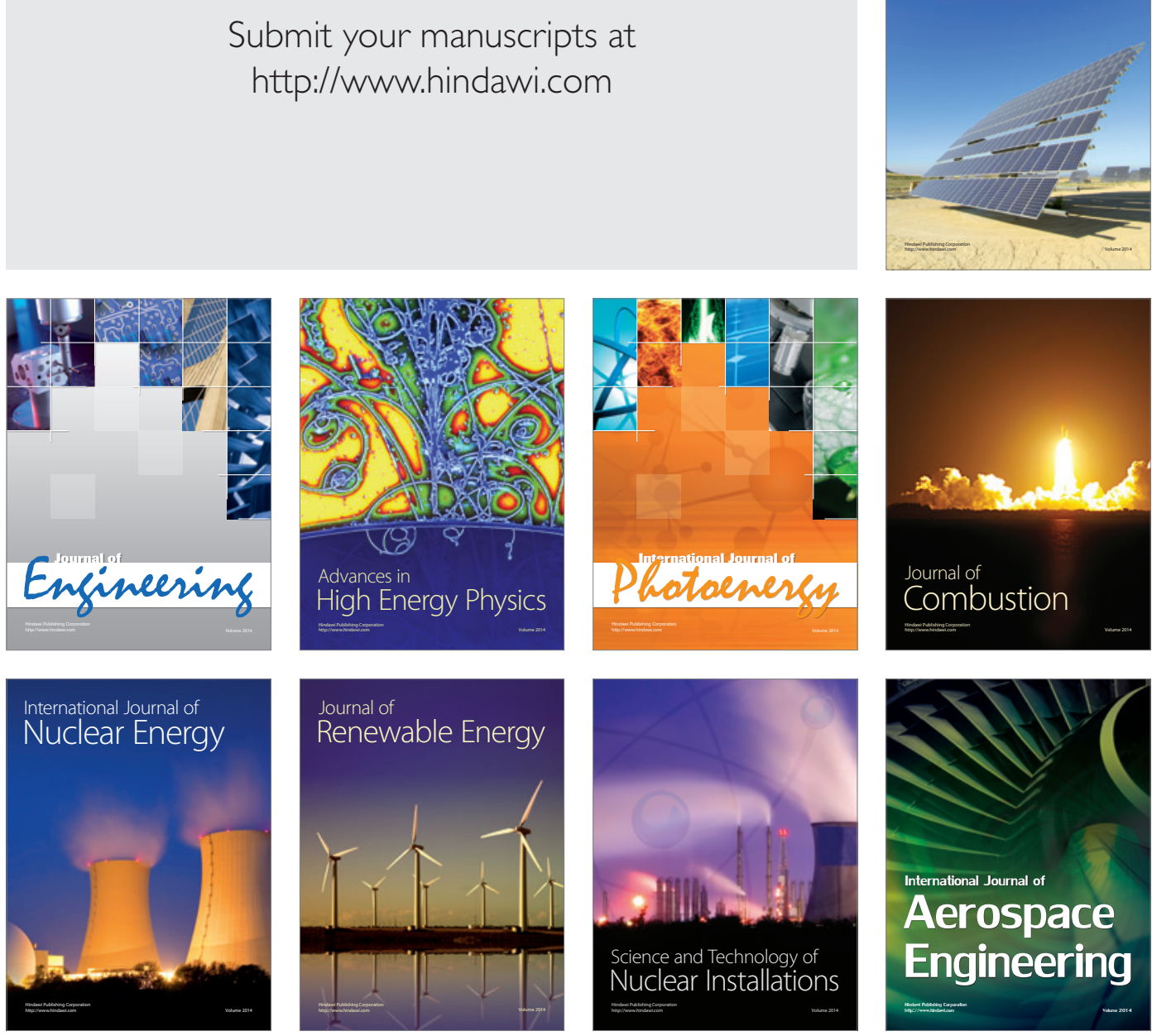